Оригинални научни рад

616-089.843:342.721

doi:10.5937/zrpfns54-26516

Dušica G. Kovačević, Ph.D., Student

University of Novi Sad

Faculty of Law Novi Sad

kovacevicdusica@rocketmail.com

\title{
ORGAN DONATION AND OWNERSHIP OF BODY PARTS: PROTECTION OF BODILY INTEGRITY
}

Abstract: Bodily integrity is one of the main areas of interest for organ transplantation. The transfer of one human organ from one body to another is a matter of the bodily integrity of the human. The focus of the work is on the treatment of the human body in situations when it is necessary to make decisions on organ donation, in one's own and others' best interests. In this context, the possibility of an equal right to bodily integrity is considered, as well as the possibility of ownership of the body. The paper will consider legislation and court cases of the European Union member states concerning the situation in the Republic of Serbia. The final part of the paper concludes about the roles that individual participants in the process of organ donation should play in modern circumstances.

Keywords: bodily integrity, autonomy, ownership of the body, organ donation, policies.

\section{INTRODUCTION}

The right to the bodily integrity of the individual is primary and essential in comparison with other personality rights. This is one of the fundamental rights that could be understood as the cornerstone of all other liberties, ${ }^{1}$ as sacred, inviolable, inalienable and fundamental, ${ }^{2}$ as the most personal, the most important of all human rights. ${ }^{3}$ There is a widespread influence that given the specific meaning of that concept could have on different issues, such as self-determination, ownership,

\footnotetext{
${ }^{1}$ Thomas Douglas, From Bodily Rights to Personal Rights, 2020.

2 Viens, A. M, Bodily integrity as a barrier to organ donation, Organ Transplantation in Times of Donor Shortage. Springer, Cham, 2016, 19-26.

${ }^{3}$ Jesse Wall Jonathan Herring. „The Nature and Significance of the Right to Bodily Integrity.” Cambridge Law Journal, 2017, 566.
} 
personal autonomy, and others. ${ }^{4}$ According to the fragility of bodily integrity, it need to be protected by the legal system. Bodily integrity could be accepted as the core legal value especially in health law. ${ }^{5}$

Many ways of using a concept of bodily integrity have different consequences and only with comparing these effects we could see that this theme could easily go to the slippery slope troubles. There are various types of bodily integrity injuries, including, among others, injuries of various types of medicines, biomedical mirrors and clinical trials, transplants (inter vivos and post mortem). The second half of the twentieth century has seen the bright study and extraordinary success in many areas of organ transplantation. Transplants of organs like kidney, skin, bones, blood vessels, and corneas have become commonplace since the mid-sixties. Since that period we are facing with increasing numbers of interventions in the field of transplantation surgery. ${ }^{6}$ Transplantation means a medical procedure, in fact, a method of treatment. Transplantation is a procedure intended to restore a certain function of the human body of the recipient of the transfer of a human organ from a human donor. ${ }^{7}$ The premise of transplantation is organ and tissue donation. We can distinguish several types of donation of body organs, cells and tissues: according to the number of persons involved in the process ${ }^{8}$, according to the time of donation - for life and after death, according to the subject of donation, due to donation legal regime, and age of the donor.

This paper will address certain law issues related to the legal status of bodily integrity in the context of organ donation through the analysis of specific court cases with this request. In the focus of this paper are countries of the European Union, with the review of law regulative in the Republic of Serbia.

\section{ORGAN DONATION ACCORDING TO LEGAL REGIME}

The field of human organ transplantation is filled with many legal sources that could be analyzed through national and international approaches. At the in-

\footnotetext{
${ }^{4}$ Radenko Jotanović, Pravo na tjelesni integritet ličnosti, Godišnjak Pravnog fakulteta $u$ Banjoj Luci, 1, 38, 35.

${ }^{5}$ Sheelagh McGuinness, Margaret Brazier, „Respecting the living means respecting the dead too", Oxford Journal of Legal Studies, 28.2/2008, 297-316.

${ }^{6}$ Thomas Starzl, „The mystique of organ transplantation”, Journal of the American College of Surgeons, 201.2/2005, 160-170.

${ }^{7}$ Zakon o presađivanju ljudskih organa, Službeni glasnik RS, br.57/2018.

${ }^{8}$ This area can be divided into organ donors and recipients, or according to the number of participants in the process of transplantation. Some countries require three physicians for confirmation of death (Belgium, Greece, Poland, Spain, Italy), two (France, Portugal) and others where single physician is enough (Austria, Finland). For more details see: Giuseppe Citerio, et al, Variability in brain death determination in Europe: looking for a solution, Neurocritical care 21.3, 2014, 376-382.
} 
ternational level exist a series of documents of the World Health Organization, declarations, and conventions on human rights governing this area. Special status has the European Convention on Human Rights and Biomedicine and its Additional Protocols on organ and tissue transplantation of human origin. ${ }^{9}$ At the level of the European Union, several action plans have been adopted in the field of organ transplantation, as well as systems, regulations. There are some European organizations involved in cross-border organ exchange: Eurotransplant, Scandiatransplant, and The South Alliance for Transplantation (SAT). ${ }^{10}$

Basically, in all EU countries, transplantation and organ donation are regulated by separated laws. Two organ donation systems have been identified: opt-in and opt-out system. An essential feature of these is to regard people as potential donors without the express consent and only those people who gave voluntary consent to be potential organ donors. Both systems leave some room for the influence of the family on the final decision when it comes to organ transplants from a person who has passed away or is unable to irradiate their will. The opt-out system is system of presumed consents: organs are allowed to be taken from deceased if he did not oppose on it while he was alive. Even if there is possibility of dilemmas about the will of deceased, taking organs is allowed. Laws on transplantation and organ donations in most countries show that we are facing with the trend of introducing this model in their legal systems in order to achieve the increasing number of potential donors. Some of the countries with this model are: Italy, France ${ }^{11}$, Spain, Belgium, Poland, Austria ${ }^{12}$, Sweden, Croatia. In one way of this system, known as "hard" one, a family has no role in deciding on organ transplantation from the body of their deceased family member. The ,soft" version of the opt-out system is characterized by the presumption in favor of donation, but the last word has a family. The opt-in system refers to the system of explicit

${ }^{9}$ Convention for the Protection of Human Rights and Dignity of the Human Being with regard to the Application of Biology and Medicine: Convention on Human Rights and Biomedicine, https://rm.coe.int/168007cf98, Accessed on 10 July, 2020.

${ }^{10}$ Study on the uptake and impact of the EU Action Plan on Organ Donation and Transplantation (2009-2015), https://ec.europa.eu/health/sites/health/files/blood_tissues_organs/ docs/2017_euactionplan_2009-2015_impact_en.pdf, Accessed on: 15 July, 2020.

${ }^{11}$ French law on this matter is characteristic. According to the law therms, French people could express their will in both cases: if they agree to be donors or if they don't want it. In both cases they are entered in the central register, and doctors are obliged to be informed about it. See in: Leo Nunnink, Chelsea Wallace-Dixon, The impact of organ donation on coronial processes and forensic investigation: A literature review, Journal of Forensic and Legal Medicine, 2020, 101940.

${ }^{12}$ The Austrian organ procurement system is one of the best developed in Europe. This country maintains one of the highest organ donation rates. This fact is a consequence of the philosophy of presumed consent, which has had deep roots in this population. One more country with similar status is Belgium. For more details see: Fabian Becker, et al, Optimizing Organ Donation: Expert Opinion from Austria, Germany, Spain and the UK, Annals of Transplantation 25, 2020, e921727-1. 
consent. Main principle of this system is that body parts of dead person can not be taken if there is no explicit consent. Certain consent must be given in the manner prescribed by law. Here, family members have the right to a subsidiary decision that the deceased one did not declare. Countries in EU that have this system are: Denmark, Germany ${ }^{13}$, the Netherlands. ${ }^{14}$ Fundamental to respecting the bodily integrity of donor is to recognize a donation in the best interests of the individual who want to be a donor, not to see potential organ donors as a source of organs for someone else. European states should made efforts to legalize this area in detail, to focus on the possibility of providing professional assistance to those in need to decide on behalf of their loved ones, to promote more broadly Organ Donor Register.

Serbian law was characterized by a mixed system, which tended more towards an explicit declaration of will. ${ }^{15}$ With the adoption of the Law on Human Organ Transplantation in 2018, the Republic of Serbia is moving to a system of presumed consent of all people for organ donation. In Serbia, two laws in the field of organ transplantation were previously in force - republican and federal, as well as part of the provisions of the law on health protection. ${ }^{16}$ Such a situation had often been created problems in interpreting regulations. The current positive legislation on this matter includes the Law on Human Cells and Tissues ${ }^{17}$, as well as the Law on Human Organ Transplantation. The very text of these laws referred to a number of decisions mostly under the authority of the Ministers of Health, regulations, and the newly established Directorate of Biomedicine.

\section{ORGAN DONATION ACCORDING TO THE SUBJECT OF DONATION}

In the idealistic understanding of bodily integrity and every other human right should be accessible equally to every human being. In order to achieve this, there is not anything wrong with the idea of preferable treatment of some vulner-

${ }^{13}$ Germany's organ donation rules have most precisely determined the circle of relatives or the case of a close person in accordance with the hints of the deceased, which is a kind of exception. For more details see: David Shaw et al, Family over rules? An ethical analysis of allowing families to overrule donation intentions, Transplantation 101.3, 2017, 482-487.

${ }^{14}$ Lee Shepherd, Ronan E. O'Carroll, and Eamonn Ferguson, An international comparison of deceased and living organ donation/transplant rates in opt-in and opt-out systems: a panel study, BMC medicine 12.1, 2014, 131.

${ }^{15}$ Luka Baturan, Stefan Samardzic, Pristanak lica da bude donor organa nakon smrti u srpskom pravu, Zbornik radova Pravnog fakulteta, Novi Sad, 4/2013, 417-434.

${ }^{16}$ Ranko Sovilj, Sanja Stojković-Zlatanović, The Legal Reform of Health Care System in the Republic of Serbia, 2017, 286-302.

${ }^{17}$ Zakon o ljudskim ćelijama i tkivima, Službeni glasnis RS, br. 57/2018. 
able groups which must be justified by especially powerful considerations. As the field of organ transplantation is still in its infancy, this necessarily means that there are no detailed legal rules that would apply to certain categories of potential organ donors. A case Polat v. Austria that recently happened (in the 2016 year) before the European Court of Human Rights concerns a prematurely stillborn whose bodily integrity was violated for the purpose of the potential use of body parts. This case concerns an autopsy performed on the body of the applicant's premature son in the absence of her expressed wish. The Court informed the Austrian Government of the request and concluded that the party had been violated under Article 8 (right to respect for private and family life), Article 9 (liberty of thoughts, consciences, and religions) and Article 13 (right to an effective remedy) of the Convention. ${ }^{18}$ But, against the fact that people have objective human rights there is a lot of examples where overriding moral considerations take precedence over autonomy. ${ }^{19}$ Here we are facing the principle with a higher power that the needs of a community are considered to be more important than the interest of an individual. If it is correct to claim that there is a general obligation to act in the public interest in certain circumstances, then there is less reason to dispute the lack of consent in a particular case. ${ }^{20}$

Bodily integrity is not only related to the idea of physical inviolability but refers to the person understanding of own body. The human mind is the cognitive side of personhood and it is a part of the growing process of one person in the connection of complex human nature. ${ }^{21}$ Both of the described terms are antipodes that create the concept of bodily integrity. Therefore, it is not surprising that it is extremely difficult to define a clear status of children, ie mentally incapable adults to decide on their body, as well as other persons who are currently deprived of the ability to clearly see the situation and interpret information. That means that the protection of bodily integrity must involve the process of making decisions over specific actions in this field. The importance of the difference in giving the relevant consent for organ donation can be seen in the fact that the donated organ with the consent is a gift, while the donated organ with the absence of consent can be considered theft. ${ }^{22}$

${ }^{18}$ European Court on Human Rights, Health-related issues in the case-law of the European Court of Human Rights, https://echr.coe.int/Documents/Research_report_health.pdf, Accessed on 10 July, 2020.

${ }^{19}$ Like some special treatment of the people with some diseases (like HIV positive people), or vaccination of people, screen diagnosis tests for pregnant women.

${ }^{20}$ Tom Woodcock, Robert Wheeler, „Law and medical ethics in organ transplantation surgery”, The Annals of The Royal College of Surgeons of England, 92.4/2010, 282-285.

${ }^{21}$ Megan Wright, End of life and autonomy: the case for relational nudges in end-of-life decision-making law and policy, Md. L. Rev. 77, 2017, 1062.

${ }^{22}$ Kieran Healy, Last best gifts: Altruism and the market for human blood and organs, University of Chicago Press, 2010. 


\section{ORGAN DONATION ACCORDING TO THE AGE OF THE DONOR}

Personality is a process, in which the mind and the body cannot be separated. Thus bodily integrity does not refer just to physical autonomy, but to the person's ability to imagine herself by the adopted observation patterns. Children could be described as pre-autonomous individuals. Depending on their level of maturity they are not able to consent to a wide range of important activities that affect them..$^{23}$ When they need to make their own informed decisions they are dependent on their caretakers. It is hard to make some decisions at a young age, maybe even harder than when a child is already dead. The loss of a child or infant is always tragic, and the opinion of an organ donation is especially hard on parents, who are decision-makers in such an event. ${ }^{24}$ Children and adolescents are less likely to provide consent for transplantation and donation, so there is a usual situation that parents of young children must make a donation decision in the absence of any knowledge about their child's donation intentions. ${ }^{25}$ Although the undisputed importance of legal theories about the bodily integrity of children, a child's moral claim to bodily integrity cannot be monolithically viewed. Any research into the strength of a child's moral demands for bodily integrity requires careful specification of the type of intervention under consideration. ${ }^{26}$

The importance of respecting bodily boundaries to support the child's ability to decide provides a necessary caveat to the sometimes uncritical endorsement of relational theory in child and health law. According to the mental ability of children and little or no experience, it is acceptable to follow principles of the relational theory that allow parents to override decisions by their children when such decisions might lead to irreparable harm or death. ${ }^{27}$ Two main arguments that are in collision here are:

1. The more helpless child is the more protection it needs;

2. There should be amended to exclude some specific categories of people and children from the generally accepted paradigm.

Mental state and cognitive impact are the main characteristics of children which contribute to the exceptional understanding of their bodily integrity. Arti217-235.

${ }^{23}$ Brian Earp, The child's right to bodily integrity, Ethics and the contemporary world, 2019,

${ }^{24}$ Marie Fox, Michael Thomson, Bodily integrity, embodiment, and the regulation of parental choice, Journal of Law and Society 44.4, 2017, 501-531.

${ }^{25}$ Jessie Hill, Constituting children's bodily integrity, Duke LJ, 64/2014, 1295.

${ }^{26}$ Imelda Coyne, et al, Children's participation in shared decision-making: Children, adolescents, parents and healthcare professionals' perspectives and experiences, European Journal of Oncology Nursing 18.3, 2014, 273-280.

${ }^{27}$ Rebecca Probert, Stephen Gilmore, Jonathan Herring, Responsible parents and parental responsibility, Bloomsbury Publishing, 2009. 
cle 19 of the Law on Patients' Rights of the Republic of Serbia ${ }^{28}$ states that in case the patient is a child, a medical measure may be taken with the consent of his/her legal representative who has been previously notified, while Article 11 of the same Law states that in the procedure of health care a child reasoning has the right to confidential counseling and without parental consent when it is in the best interests of the child. According to the prescribed conditions for donating human organs of a deceased person of the Law on Transplantation of Human Organs from a deceased minor who lived without parental care, it is allowed to take human organs only with the consent of the ethics board of a specific health institution

An example of a breach of the relevant consent provisions can be seen in the case Petrova v. Latvia (2014). The applicant's son was taken to the hospital because he had sustained life-threatening injuries that were inflicted on him in a car accident. He died in the hospital, and shortly afterward, a laparotomy was performed on his body, in the course of which his kidneys and spleen were removed for organ-transplantation purposes. The applicant alleged that the removal of her son's organs had been carried out without her son's prior consent. She added that no attempt had been made to establish her views on that procedure. The Court held that there had been a violation of Article 8 of the European Convention on Human Rights. The conclusion was that the Latvian law in the area of organ transplantation which was in effect at the time of the death of the applicant's son hadn't been sufficiently clear. Such a situation had resulted in circumstances whereby the applicant, as the closest relative to her son, had certain rights with regard to removal of his organs and their donation, but was not informed about that and was not informed about the process of transplantation. The sum is that the Latvian law on the organ donation did not clearly define the corresponding obligation or discretion of experts to obtain consent. ${ }^{29}$

\section{ORGAN DONATION ACCORDING TO THE TIME OF DONATION-DURING LIFE OR DEATH}

Considering many values, convictions, and motives, donor families and non-donor families came to different decisions. The main utilitarian principle is that body parts are worthless after death and it could be easily given to persons that need them. Values that are most considered in this context are aiding other people, giving them a better life, reciprocity. Others respect the sanctity of given human life and they usually promote a specific perspective of the integrity of the body. The certain value that is needed to be protected is the body of the deceased,

${ }^{28}$ Zakon o pravima pacijenata, Službeni glasnik RS, br. 45/2013 i 25/2019- dr. zakon.

${ }^{29}$ Council of Europe, https://hudoc.echr.coe.int/sites/eng?i=001-144997, Accessed on 11 July, 2020. 
which is often combined with the conviction of the family members that they have the right to make decisions over the dead body. Some authors, as Mill is, emphasize the importance of bodily integrity in connection with the principle of self-ownership. If every individual person is sovereign over her body than it implies that each person is the proper guardian of his own health. ${ }^{30}$ Body ownership could be described by sensing our body as the specific material that we feel instinctively for our own. Property is a complex issue that can be conceptualized in progressive ways. Granting property rights over one's body and body parts and products can enhance one's ability to make autonomous choices and control what happens to one's body. ${ }^{31}$ Bodily integrity is often a place of a collision between individual, self-interest, and paternalistic interest of a state. This certain point of disagreement usually involves issues such as public health, integrity of medical profession, criminal consequences, national security and welfare, and the preservation of life.

Whether a person has an ethical duty or responsibility to take action. Almost all scientists agree that voluntary organ donation is acceptable. There is some disagreement as to whether it is desirable for all humans to donate their organs after death. Those who need organs are put on legal waiting lists indefinitely many die while still on the waiting list. The demand for organs in the EU far exceeds the supply both at the level of the whole community and individual countries. At the end of 2015, a total of 56,000 patients were on waiting lists in the EU. The modern state generally has a legal system for monitoring organ transplants. In contrast, there is a black market trend often referred to as transplant tourism. The year 2013 was typical for Germany due to changes in legislation due to the increase of inadequate application of the law in the context of the discovered manipulation in terms of giving benefits to wealthy patients and links with an organized crime of organ trafficking. ${ }^{32}$ The case Elberte v. Latvia (2015 year) concerns the removal of body tissue from the applicant's husband by a forensic expert after his death in the absence of her knowledge or consent. The tissue had been removed from the husband's body after the autopsy and sent to the pharmaceutical company in Germany for the creation of bio-implants. Two years after the death of her husband, a criminal investigation was launched in Latvia on the widespread illegal removal of organs and tissues from the logs, but the domestic authorities did not determine the elements of the crime in this case. The applicant complained to the European Court on emotional suffering due to uncertainty as to the circumstances of the removal of the tissue from her husband. The Court finds that there has been a violation of Article 8 and a violation of Article 3 (pro-

\footnotetext{
${ }^{30}$ John Stuart Mill, On Liberty, 1892.

${ }^{31}$ Donna Dickenson, Property in the Body, Cambridge University Press, Vol. 39, 2017.

32 Ștefănuț Radu, Criminological Analysis of the Crime Concerning Organ Trafficking, EIRP Proceedings 15.1, 2020.
} 
hibition of inhuman or degrading treatment) of the Convention, emphasizing that the human body is worthy of respect even after death. ${ }^{33}$

The Republic of Serbia has incriminated organ trafficking through legal solutions that regulate transplantation, but the prohibition is also contained in the Criminal Code itself. ${ }^{34}$ The penal provisions of the Law on Human Organ Transplantation contain a description of a large number strictly prohibited actions. Actions by which consent is extorted, by which transplantation is performed to a person who has not given written consent, by whom the organ is taken from the deceased when he/she has not been diagnosed brain death or transplantation performed without the consent of family members are punishable. Those crimes are punishable by two to ten years in prison. ${ }^{35}$

Constant reflection on conventional arguments about bodily integrity serves to create enhanced protection that provides defense against unwarranted outside influence. Some medical principles prevent doctors from entering bodies without consent, beside in exceptional circumstances. A concrete example includes the concepts of dignity, inviolability of the person and bodily integrity and uses the metaphors of invasion to describe the complexity of the problem of imposing any use of human organs in an inhuman and degrading way. From a legal point of view, an organ transplant performed by a living donor is significantly different from a transplant from a dead donor. There are several prerequisites for a transplant from a living donor: if the donor is an adult and legally capable person, if he has given written consent, if a risk assessment for the life and health of the donor has been performed, if an ethics committee has given its consent. ${ }^{36}$ The special position of the deceased has practical significance. In order for organs of deceased to be used, it is necessary to respect the right to self-determination of the deceased, respecting the formal-legal criteria and determining the moment of his death. Within the legislation of the member states of the European Union, there is an opinion that brain death is legally recognized. ${ }^{37}$ Such an argument is most adequately presented in the German transplantation law, which states that organ transplantation from the deceased is allowed if such death is established according

${ }^{33}$ Council of Europe, https://hudoc.echr.coe.int/sites/fra/pages/search.aspx?i=001-150234, Accessed on 30 June, 2020.

${ }^{34}$ Krivični zakonik, Službeni glasnik RS, br. 85/05, 107/05, 72/09, 111/09, 121/12, 104/13, 108/14, 94/16 i 35/19.

${ }^{35}$ Miroslav Lazic, Ivana Simonovic, The Principles of Human Organ Transplantation Procedure, Collection Papers Fac. L. Nis 85, 2019, 15.

${ }^{36}$ Zakon o presađivanju ljudskih organa, Službeni glasnik RS, br.57/2018.

${ }^{37}$ Some countries, like Italy, functioned with laws that were based over 20 years on detailed clinical descriptions based on concepts that are outdated in relation to scientific progress; yet it was necessary to respect them since they were set in law. For more detail see: Paola Bin, et al, Donation of the body for scientific purposes in Italy: ethical and medico-legal considerations, Open Medicine 11.1, 2016, 316-320. 
to the latest medical science, and determined by legal rules defining brain death as finally, the irreversible extinction of the functions of the cerebellum and brainstem. ${ }^{38}$

The basic principle on which the donation of vital organs from the dead is based is called the „rule of the dead donor”, which is a protective fact for both doctors and for all concerned. This position has been criticized for relying on the conceptual design of the definition of brain death. It is necessary to consider more widely the justification of organ donation of the persons that are in the dying stage. An example of a situation in which a new paradigm would provide wider benefits in the field of organ transplantation is the case of anencephalic newborns. Placing this newborn on a respirator until brain death usually only prolongs the dying process without improving the chances of organ donation. When brain death occurs the general condition of organs isn't optimal and that organs can no longer be used. The best-proposed alternative would require an extension of this newborns from the legal definition of death. Newborn organ donation has not been available in Europe for many years. Contrary to that fact, such successful kidney transplants have been described in Germany and Spain as heart transplants in Italy. The United Kingdom is the only European country that supports national guidelines in this area. The case of Denmark in the 1980s, and later Germany, are classic examples of certain categories being excluded from the definition of brain death in certain situations. In both cases, the controversy caused by the discussion on the definition of brain death caused a long-term large reduction in the rate of organ donations. ${ }^{39}$

It is worth mentioning future controversial cases that will certainly happen due to the accelerated development of biomedicine. In the case of Parrillo v. Italy, the applicant appealed against the legislation donation ban for cryopreserved embryo research which was created after in vitro fertilization of the applicant (IVF) treatment. The applicant used it in 2002 in the IVF treatment with a partner. Her partner died in 2003. The applicant did not want that to continue the pregnancy and requested the release of the embryo so she could donate them for stem cell research. The clinic refused to comply with that request, so the embryos remained in the cryogenic storage depot. The applicant mainly appealed to the Court under Article 8 Convention and Article 1 of Protocol No. 1 1- legal prohibition. The Court found that there were no violation of the certain legal rules. The Court had to decide for the first time whether the notion of ,private life" in Article 8 refers to the applicant's wish to get embryos that are the result of her IVF treatment, and which are not destined to be used for the purpose for which they were created. ${ }^{40}$

\footnotetext{
${ }^{38}$ Björn Nashan, et al, Transplantation in Germany, Transplantation 101.2, 2017, 213-218.

${ }^{39}$ Rafael Matesanz, Cadaveric organ donation: Comparison of legislation in various countries of Europe, Nephrology Dialysis Transplantation, 13(7), 1998, 1632-1635.

${ }^{40}$ European Court on Human Rights, Overview of the Court's case-law (2015), https://echr. coe.int/Documents/Short_Survey_2015_ENG.pdf, Accessed on 13 July, 2020.
} 


\section{CONCLUSION}

The legal principles that we universally follow in organ donation and transplantation are important for both the current optimal state and the future because they can be used to resolve our conflicts related to new sciences such as cloning, tissue engineering, and stem cells. The value of the traditional doctrine of bodily integrity involves the human embodiment that is part of the integrity. That should contribute to the observation of the body as an integral part of our ontology. It is crucial to reconsider the concept of bodily integrity in relation to controversial individual cases and in line with the biomedical achievements.

It is important to accept widely the integration of the physical and mental dimensions of the body and health in order to avoid their dilution, which, as we have seen, contributes to the problematic status of the legal subject and continues to further structure dominant legal understandings of bodily integrity. Respect for generally accepted standards of bodily integrity in practice confirms the need for new, advanced standards, tailored to current results of researches on human body. This approach recognizes that bodies are not only instrumentally valuable, but they also are ,integral to who we are" and who we can become. ${ }^{41}$ Despite this, what real interest do we have in our bodies? Do the kinds of interests we have in our body dissapear on death or do they carry on? Only through an optimal answer to the above and more questions, we can estimate which of the legal subsystems has broader support for the management of bodily organ donation situations.

The development of biomedical technologies has caused many changes in social communities. Various opportunities have often been created, accompanied by moral dilemmas and the difficulties of the legal formulation. The intensification of scientific contributions that can directly manipulate life interruptions has led to the complication of theories about individual human rights. It is important to point out the banality of various legal solutions in this sphere, precisely in relation to the fact that these are countries that are part of a Europe that is becoming unified and in which borders are slowly losing their significance.

\section{REFERENCES}

Björn Nashan, et al, Transplantation in Germany, Transplantation 101.2, 2017.

Brian Earp, The child's right to bodily integrity, Ethics and the contemporary world, 2019.

Convention for the Protection of Human Rights and Dignity of the Human Being with regard to the Application of Biology and Medicine: Convention on Human Rights and Biomedicine, https://rm.coe.int/168007cf98, Accessed on 10 July, 2020.

${ }^{41}$ Eva Feder Kittay, Forever small: The strange case of Ashley X, Hypatia 26.3, 2011, 610-631. 
Council of Europe, https://hudoc.echr.coe.int/sites/eng?i=001-144997, Accessed on 11 July, 2020.

Council of Europe, https://hudoc.echr.coe.int/sites/fra/pages/search.aspx?i=001150234, Accessed on 30 June, 2020

David Shaw et al, Family over rules? An ethical analysis of allowing families to overrule donation intentions, Transplantation 101.3, 2017.

Donna Dickenson, Property in the Body, Cambridge University Press, Vol. 39, 2017.

European Court on Human Rights, Health-related issues in the case-law of the European Court of Human Rights, https://echr.coe.int/Documents/Research_report health.pdf, Accessed on 10 July, 2020.

European Court on Human Rights, Overview of the Court's case-law (2015), https:// echr.coe.int/Documents/Short Survey_2015_ENG.pdf, Accessed on 13 July, 2020.

Eva Feder Kittay, Forever small: The strange case of Ashley X, Hypatia 26.3, 2011.

Fabian Becker, et al, Optimizing Organ Donation: Expert Opinion from Austria, Germany, Spain and the UK, Annals of Transplantation 25, 2020.

Giuseppe Citerio, et al, Variability in brain death determination in Europe: looking for a solution, Neurocritical care 21.3, 2014.

Imelda Coyne, et al, Children's participation in shared decision-making: Children, adolescents, parents and healthcare professionals' perspectives and experiences, European Journal of Oncology Nursing 18.3, 2014.

Jessie Hill, Constituting children's bodily integrity, Duke LJ, 64/2014.

Jesse Wall Jonathan Herring, The Nature and Significance of the Right to Bodily Integrity, Cambridge Law Journal, 2017.

John Stuart Mill, On Liberty, 1892.

Kieran Healy, Last best gifts: Altruism and the market for human blood and organs, University of Chicago Press, 2010.

Krivični zakonik, Službeni glasnik RS, br. 85/05, 107/05, 72/09, 111/09, 121/12, 104/13, 108/14, 94/16 i 35/19.

Lee Shepherd, Ronan E. O'Carroll, and Eamonn Ferguson, An international comparison of deceased and living organ donation/transplant rates in opt-in and opt-out systems: a panel study, BMC medicine 12.1, 2014.

Leo Nunnink, Chelsea Wallace-Dixon, The impact of organ donation on coronial processes and forensic investigation: A literature review, Journal of Forensic and Legal Medicine, 2020.

Luka Baturan, Stefan Samardzic, Pristanak lica da bude donor organa nakon smrti u srpskom pravu, Zbornik radova Pravnog fakulteta, Novi Sad, 4/2013.

Marie Fox, Michael Thomson, Bodily integrity, embodiment, and the regulation of parental choice, Journal of Law and Society 44.4, 2017.

Megan Wright, End of life and autonomy: the case for relational nudges in end-of-life decision-making law and policy, Md. L. Rev. 77, 2017.

Miroslav Lazic, Ivana Simonovic, The Principles of Human Organ Transplantation Procedure, Collection Papers Fac. L. Nis 85, 2019.

Paola Bin, et al, Donation of the body for scientific purposes in Italy: ethical and medico-legal considerations, Open Medicine 11.1, 2016.

Radenko Jotanović, Pravo na tjelesni integritet ličnosti, Godišnjak Pravnog fakulteta u Banjoj Luci, 1, 38. 
Rafael Matesanz, Cadaveric organ donation: Comparison of legislation in various countries of Europe, Nephrology Dialysis Transplantation, 13(7), 1998.

Ranko Sovilj, Sanja Stojković-Zlatanović, The Legal Reform of Health Care System in the Republic of Serbia, 2017.

Rebecca Probert, Stephen Gilmore, Jonathan Herring, Responsible parents and parental responsibility, Bloomsbury Publishing, 2009.

Sheelagh McGuinness, Margaret Brazier, Respecting the living means respecting the dead too, Oxford Journal of Legal Studies, 28.2/2008.

Ştefănuț Radu, Criminological Analysis of the Crime Concerning Organ Trafficking, EIRP Proceedings 15.1, 2020.

Study on the uptake and impact of the EU Action Plan on Organ Donation and Transplantation (2009-2015), https://ec.europa.eu/health/sites/health/files/blood tissues_organs/docs/2017_euactionplan_2009-2015_impact_en.pdf, Accessed̄on: 15 Jüly, 2020.

Thomas Douglas, From Bodily Rights to Personal Rights, 2020.

Thomas Starzl, „The mystique of organ transplantation”, Journal of the American College of Surgeons, 201.2/2005

Tom Woodcock, Robert Wheeler, „Law and medical ethics in organ transplantation surgery", The Annals of The Royal College of Surgeons of England, 92.4/2010.

Viens, A. M, Bodily integrity as a barrier to organ donation, Organ Transplantation in Times of Donor Shortage. Springer, Cham, 2016.

Zakon o ljudskim ćelijama i tkivima, Službeni glasnis RS, br. 57/2018.

Zakon o pravima pacijenata, Službeni glasnik RS, br. 45/2013 i 25/2019- dr. zakon.

Zakon o presađivanju ljudskih organa, Službeni glasnik RS, br.57/2018. 


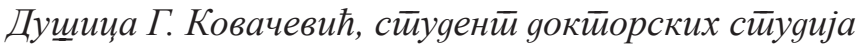

Универзииетеи у Новом Саяу

Правни факулиетеи у Новом Саgу

kovacevicdusica@rocketmail.com

\section{Донирање органа и власништво над деловима тела: заштита телесног интегритета}

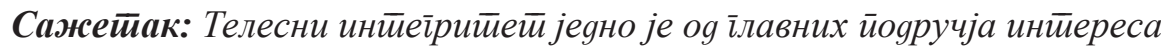



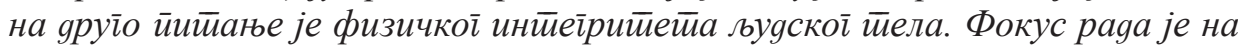



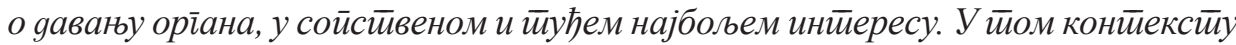

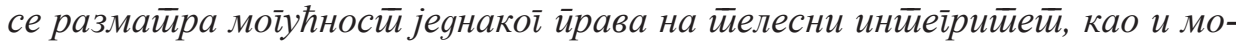

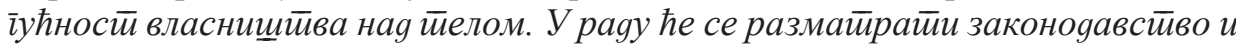
судски случајеви земаљь чланица Евройске уније узимајући у обзир и сийуаиију у Рейублици Србији. Заврщини део раяа закључује о улоїама које йојеgини учесници у йроцесу донирања орі̄ана т̄реба gа иірају у савременим околностиима.

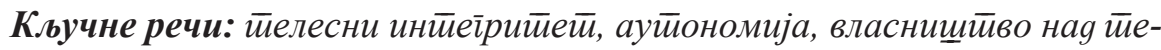
лом, донирање орїана, йолийике.

Датум пријема рада: 10.5.2020. 